\title{
Biological effects of inhaled magnesium sulphate whiskers in rats
}

Hajime Hori, Takahiko Kasai, Joji Haratake, Sumiyo Ishimatsu, Takako Oyabu, Hiroshi Yamato, Toshiaki Higashi, Isamu Tanaka

\begin{abstract}
Male Wistar rats were exposed to two types of magnesium sulphate whiskers by inhalation for six hours a day, five days a week, for four weeks (sub-chronic study), or for one year (chronic study) to clarify the biological effects of the whiskers. There were few whiskers detected in the rat lungs even at one day after the exposure, suggesting that they are dissolved and eliminated rapidly from the lungs. To measure the clearance rate of the whiskers from the lungs, an intratracheal instillation was performed in golden hamsters. The half life of the whiskers in the lung was determined as $\mathbf{1 7 . 6}$ minutes by temporally measuring the magnesium concentration up to 80 minutes after the instillation. A histopathological examination indicated a frequent occurrence of adenoma and carcinoma in the year after chronic exposure, but it was not significantly different between exposed and control rats.
\end{abstract}

(Occup Environ Med 1994;51:492-499)

Department of

Environmental Health Engineering, Institute of Industrial

Ecological Sciences

H Hori

$S$ Ishimatsu

T Oyabu

$\mathrm{H}$ Yamato

I Tanaka

Department of

Pathology and

Oncology, School of

Medicine

T Kasai

J Haratake

Department of Work Systems and Health, Institute of Industrial Ecological Sciences, University of

Occupational and

Environmental

Health, Japan

Kitakyushu 807, Japan

T Higashi

Correspondence to:

Dr Hajime Hori,

Department of

Environmental Health

Engineering, Institute of

Industrial Ecological

Sciences, University of

Occupational and

Environmental Health,

Japan, 1-1 Iseigaoka

Yahatanishi-ku, Kitakyushu 807, Japan.

Accepted for publication 18 March 1994
Many kinds of manmade mineral fibres (MMMFs) have been developed in recent years as asbestos substitutes or as reinforcements, insulators, and friction materials. Magnesium sulphate whisker is an MMMF synthesised from magnesium sulphate and magnesium hydroxide by hydrothermal reaction at $100-300^{\circ} \mathrm{C}$. It is used as a reinforcement for plastics and rubbers and a thickener of paint materials and epoxy adhesives.

In general, not only asbestos but also respirable long fibres with a small diameter have been suspected of exerting strong biological effects-for instance, acting as carcinogens. ${ }^{12}$ To verify this hypothesis, many in vivo ${ }^{3-5}$ and in vitro $^{6-8}$ studies have been reported for MMMFs, especially for glass fibres, ceramic fibres, and slug/rock fibres. Magnesium sulphate whisker is a fibrous material with a large aspect ratio, so that some biological effects might be suspected. The effects of magnesium sulphate whisker have not been established yet, however, because it is a newly developed material. Adachi et al ${ }^{9-11}$ showed an increase in tumours in hamsters that were given magnesium sulphate whisker by intratracheal instillation, but there is no report available on inhalation studies that resemble actual exposure in the work environment.

Recently, it has been shown that the chemi- cal properties of fibres, as well as their geometric characteristics, are important factors for biological effects. For example, the fibres that have lower solubility will persist longer in the body. The surface charge might be associated with pathogenicity, ${ }^{12}$ and acid treatment was effective in decreasing pathogenicity of the fibres, ${ }^{13}$ suggesting that differences in chemical characteristics could cause different interactions between the tissues and fibres even when the geometrical sizes are the same.

The purpose of the present study was to investigate biological effects of magnesium sulphate whisker. As it is important to know the basic characteristics of the whiskers, some physical and chemical properties that may be associated with biological effects were measured in advance of animal experiments. Then, rats were exposed to the whiskers by inhalation to establish the durability and histopathological effects of the whiskers. The clearance rate of the whiskers in the lungsthat is, an index of durability-was determined by temporally measuring the amounts of magnesium in the lungs after intratracheally injecting the whiskers into hamsters.

\section{Methods}

MEASUREMENT OF PHYSICAL AND CHEMICAL CHARACTERISTICS OF WHISKERS

Materials

Whiskers studied consisted of magnesium sulphate and magnesium hydroxide $\left(\mathrm{MgSO}_{4}\right.$ $\left.5 \mathrm{Mg}(\mathrm{OH})_{2} 3 \mathrm{H}_{2} \mathrm{O}\right)$, commercial name; MOSHIGE (UBE industries, Japan). Two types of whiskers, short whiskers (USW) and long whiskers (ULW) were examined.

Length and diameter of the whiskers

A scanning electron microscope (Hitachi, S700 , Japan) was used to obtain the distribution of whisker lengths and diameters. The measurements were taken in accordance with the WHO method. ${ }^{14}$ Because MOS-HIGE is soluble in water, the whiskers were suspended in cyclohexane and collected on a nucleopore filter (25 mm diameter, pore size $0.25 \mu \mathrm{m}$ ). Photos were taken at a magnification of 2000 . The magnification was increased up to 20000 to obtain a higher accuracy for measuring whiskers with a small diameter. The diameter and the length of the whiskers were measured with a backlight digitiser (Graphtec, Japan, $\mathrm{KD}-3030 \mathrm{D}$ ). The diameter was measured at the centre of the whisker and the length was measured along the curve on the developed negative films or enlarged photos. 
Figure 1 Experimental apparatus.

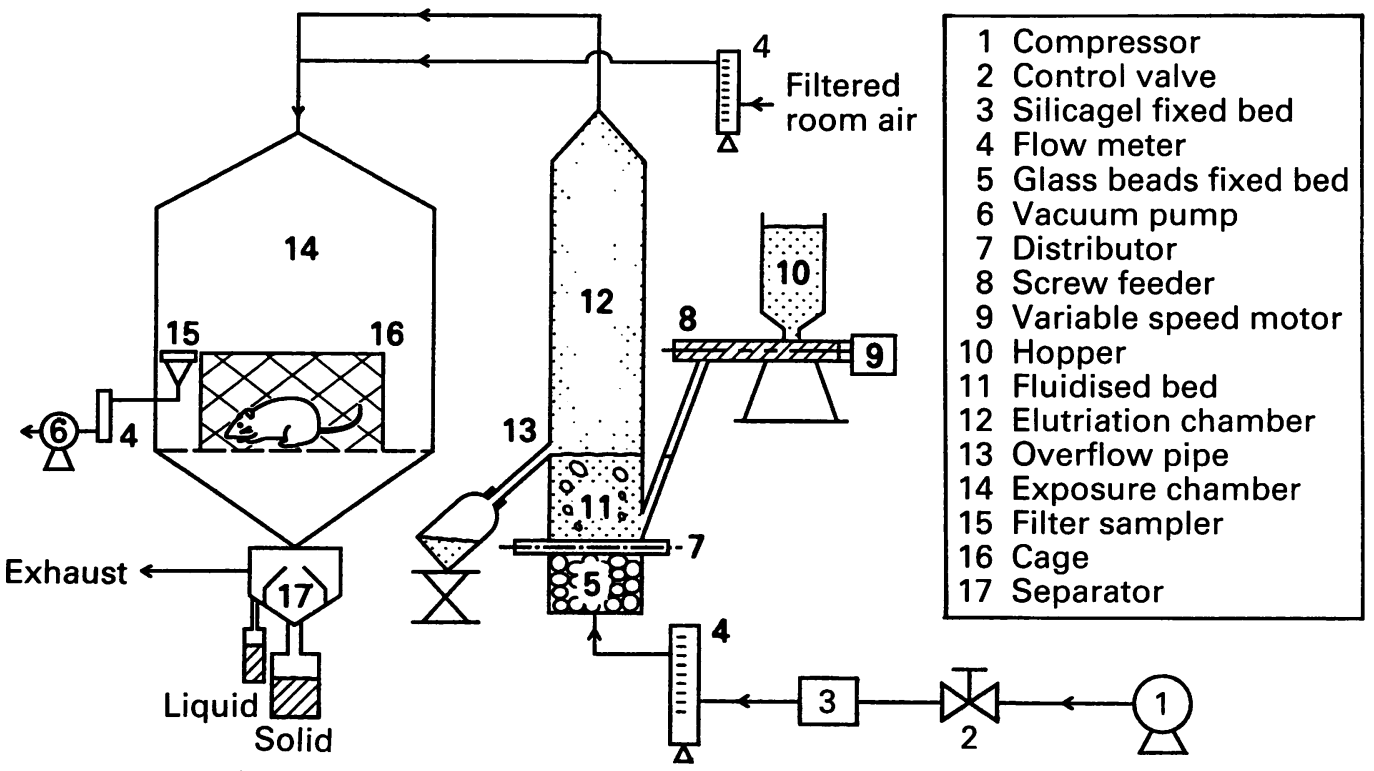

Surface area

Samples $(0 \cdot 2-0 \cdot 5 \mathrm{~g})$ were packed in a cell, and the surface area of the whiskers was measured by the one point BET method with an auto surface area analyser (Flowsorb II 2300, Shimadzu, Japan).

True and bulk density

The true density was measured by the picnometer method with an Auto True Denser (MAT-5000, ENTERPRIZE). The bulk density was measured according to the JIS K5101 method, ${ }^{15}$ as follows. The whiskers were put on a sieve and dispersed down to a funnel by softly wiping on the sieve with a brush. The whiskers were received in a collector, the contents were weighed, and the bulk density was calculated.

\section{Solubility and $p H$}

Two hundred milligrams of the whiskers were put into four $300 \mathrm{ml}$ Erlenmeyer flasks with ground in stoppers. The flasks contained one of: $200 \mathrm{ml}$ of distilled water, physiological saline, Gamble's solution, or phosphoric acid buffer solution. The temperature of the solutions was kept at $37^{\circ} \mathrm{C}$. The flasks were left in an incubator with shaking. Parts of the solutions were filtered with a membrane filter (pore size $0.1 \mu \mathrm{m}$ ) at $5,10,20,30,60$, and 120 minutes after the beginning of dissolution. For some samples, the dissolution time was prolonged up to 21 days. The dissolved magnesium concentrations were determined with an inductively coupled plasma spectrophotometer (ICP, Model 500, Shimadzu,

Table 1 Experimental conditions

\begin{tabular}{|c|c|c|c|c|}
\hline & \multicolumn{2}{|c|}{ Subchronic exposure } & \multicolumn{2}{|c|}{ Chronic exposure } \\
\hline & $\begin{array}{l}\text { Short } \\
\text { whisker }\end{array}$ & $\begin{array}{l}\text { Long } \\
\text { whisker }\end{array}$ & $\begin{array}{l}\text { Short } \\
\text { whisker }\end{array}$ & $\begin{array}{l}\text { Long } \\
\text { whisker }\end{array}$ \\
\hline $\begin{array}{l}\text { Concentration }\left(\mathrm{mg} / \mathrm{m}^{3}\right) \\
\text { Whisker diameter }(\mu \mathrm{m})^{\star} \\
\text { No of rats } \\
\text { Exposure period } \\
\text { Total exposure time }(\mathrm{h})\end{array}$ & $\begin{array}{r}2 \cdot 3(0 \cdot 7) \\
42^{1 \cdot 5(3 \cdot 0)} \\
4\end{array}$ & $\begin{array}{l}4 \cdot 0(1 \cdot 1) \\
1 \cdot 8(2 \cdot 5) \\
42 \\
\text { eks }\end{array}$ & $\begin{array}{l}1 \cdot 1(0 \cdot 6) \\
27.5(3 \cdot 0)\end{array}$ & $\begin{array}{l}1 \cdot 4(0 \cdot 6) \\
1 \cdot 8(2 \cdot 5) \\
27 \\
\text { ear } \\
12\end{array}$ \\
\hline
\end{tabular}

^Median diameter (geometric SD).
Japan). Simultaneously, $\mathrm{pH}$ in the fluids was measured with a $\mathrm{pH}$ meter (Horiba, Japan).

\section{Zeta potential}

Whiskers were put into distilled water, physiological saline, or Gamble's solution and suspended by ultrasonic vibration. Parts of the solutions (samples) were transferred to a crystal cell and the zeta potential measured by determining the electrophoretic mobility with a zeta potential analyser (Laser Zee Model 501, Pen Kem, USA) equipped with a microscope. A helium-neon laser was used as a light source.

\section{Analysis of metal elements}

The major metal component of the whisker is magnesium. Magnesium content was measured by a titration method. ${ }^{16}$ Other trace elements were measured with an ICAP spectrophotometer (ICAP-575 Mark II, Nippon Jarrell Ash, Japan).

\section{INTRATRACHEAL INSTILLATION}

The short whiskers $(2 \mathrm{~g})$ were suspended in $500 \mathrm{ml}$ of distilled water, and $0.275 \mathrm{ml}$ of the suspension (1.1 $\mathrm{mg}$ of whiskers) was intratracheally injected into the lungs of each of 30 golden hamsters. The same amounts of distilled water were injected into five hamsters as a control group. Hamsters were killed and dissected at 10,20, 40,60, and 80 minutes after the injection, and the amounts of magnesium in the lungs were determined by a wet ashing method (see later). The residual amounts of the whiskers were calculated from the amounts of magnesium.

\section{INHALATION STUDY}

Experimental apparatus

Figure 1 shows a schematic diagram of the inhalation exposure system. It consists of a whisker generator and an exposure chamber.

Whiskers were premixed with glass beads $(250 \mu \mathrm{m})$ and put into a hopper (10). The whiskers mixed with glass beads were supplied from the hopper to a fluidised bed 


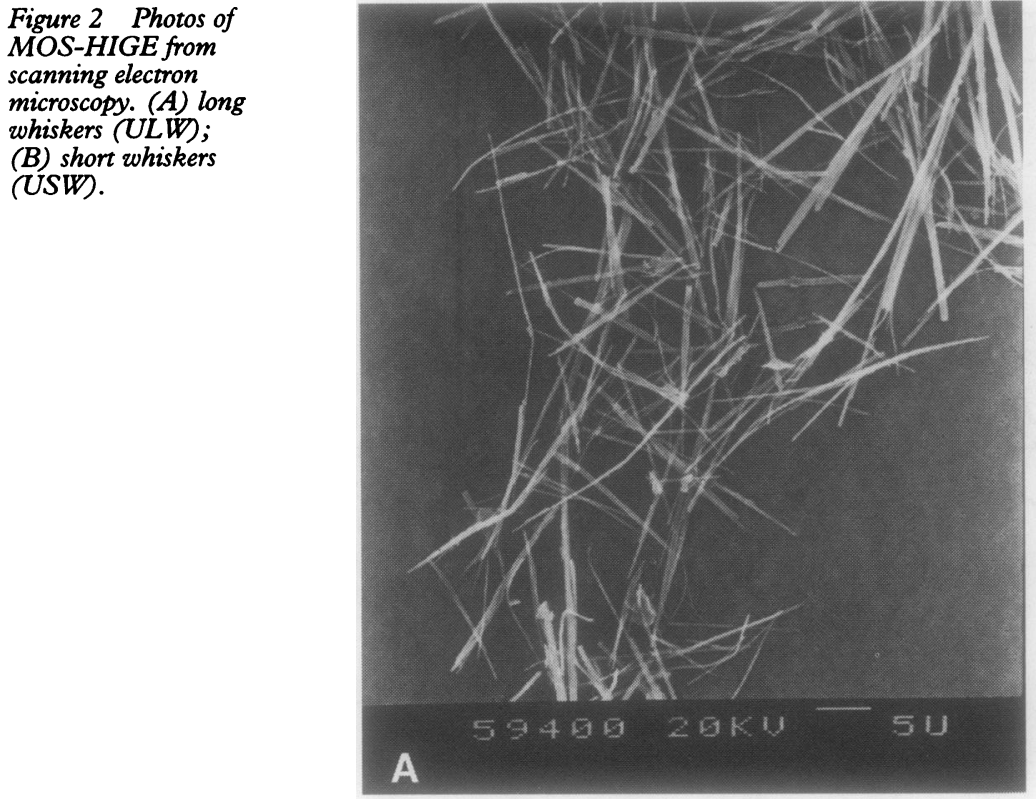

generator (11) developed by Tanaka et $a l^{17}$ at a constant rate by a screw feeder (8). Air from a compressor was passed through a silica gel fixed bed (3) for dehumidification, then introduced into the bottom of the fluidised bed where glass balls (5-10 $\mathrm{mm}$ in diameter) were packed up to $25 \mathrm{~cm}$ high to obtain a steady flow. The glass beads with whiskers were moved vigorously in the fluidised bed due to airflow and the whiskers were detached from the glass beads. Because of the difference of the sedimentation rate and the air velocity, only whiskers were eluted from the top of the bed and transported to the exposure chamber by air. The glass beads and aggregated whiskers were discharged from an overflow pipe to a stacker.

The exposure chamber (volume $0.43 \mathrm{~m}^{3}$ ) was made from stainless steel. Air with whiskers was introduced from the top of the chamber with a flow rate of $150 \mathrm{1} / \mathrm{min}$ and evacuated from the bottom. The exhaustion air was discharged after passing through an air cleaner. The whisker concentration in the chamber was monitored continuously with a digital dust indicator (Model AP-638, Shibata Scientific, Japan). To determine the concentration, the whiskers in the chamber were collected on a filter paper with a sampling pump. The aerodynamic diameter of the whiskers and their size distributions were determined by sampling the whiskers with an Andersen cascade impactor (Model 3351, Kanomax, Japan).

\section{Exposure conditions and methods}

Three exposure chambers were used for the inhalation studies. One was for the control group and the others were for the short whisker and long whisker exposure groups. The temperature and the humidity in the chambers were controlled to $25^{\circ} \mathrm{C}$ and $50 \%$. Two sets of experiments - that is, four weeks subchronic exposure and one year chronic exposure-were carried out. Table 1 summarises the experimental conditions. In each

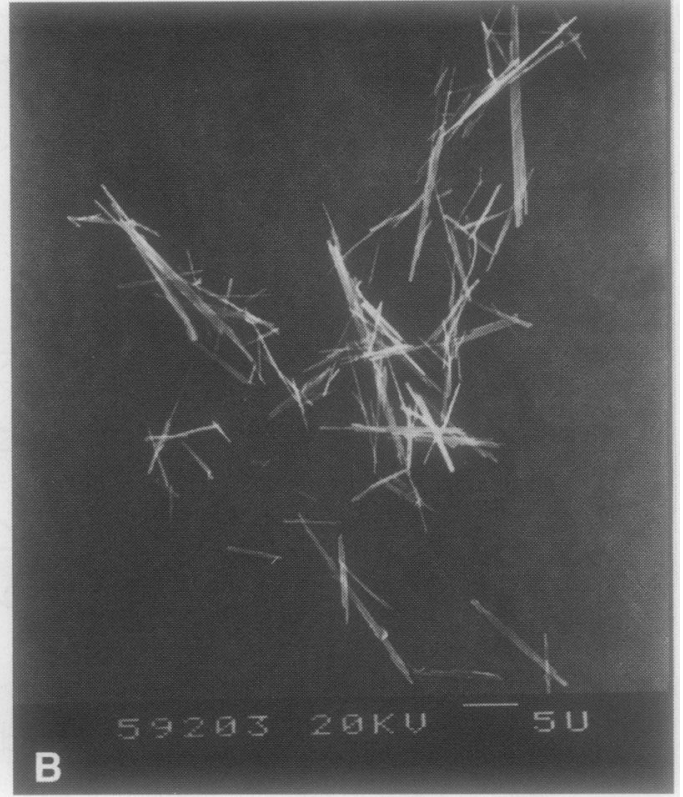

experiment, male Wistar rats (four weeks old) were exposed to the whiskers for six hours a day, five days a week. Body weights of the rats were measured every week to obtain the growth curves.

In the subchronic exposure study, 124 rats were randomly divided into three groups (42, 42, and 40 rats per group for short whiskers, long whiskers, and controls, respectively). Five or six rats in each group were killed and dissected at one, two, three, and four weeks after the beginning of the exposure, and two and four weeks, six months, and one year after the end of the exposure.

In the chronic study, 80 rats were randomly divided into 27,27 , and 26 for short whiskers, long whiskers, and control groups, respectively. The dissection was conducted at one day and one year after the end of the exposure.

In all dissections, the weights of body and organs (lung, liver, kidney, and spleen) were measured. Lungs were divided and a part was used for the determination of the whiskers. Remaining portions were used for histopathological examination.

\section{Measurement of magnesium in the lung}

The amounts of magnesium in the lungs were determined by the wet ashing method with a Microdigest (Model 300, Prolabo, France). About 0.5 to $1 \mathrm{~g}$ of the samples were put into the Microdigest and the tissues were removed by treating with $0.5 \mathrm{ml}$ of sulphuric acid, 4.0 $\mathrm{mg}$ of nitric acid, and $0.5 \mathrm{ml}$ of hydrogen peroxide. The residual solutions were diluted to $50 \mathrm{ml}$ with distilled water and the amounts of magnesium were measured with an ICP spectrophotometer at $279.553 \mathrm{~nm}$.

\section{Histopathological examination}

Rats were anaesthetised by sodium pentobarbitone, ( $50 \mathrm{mg} / \mathrm{kg}$ body weight), and killed for necropsy after the sampling of blood. Whole organs were examined carefully by eye. Portions of both lungs, liver, kidneys, 
Table 2 Physical and chemical properties of MOS-HIGE

\begin{tabular}{llcc}
\hline & Method & Long whisker & Short whisker \\
\hline Count median length $(\mu \mathrm{m})$ & SEM & $12 \cdot 0(2 \cdot 3)^{*}$ & $4 \cdot 9(2 \cdot 1)^{*}$ \\
Count median diameter $(\mu \mathrm{m})$ & SEM & $0 \cdot 44(1 \cdot 6)^{*}$ & $0 \cdot 31(1 \cdot 5)^{*}$ \\
Aspect ratio & & $27 \cdot 3$ & $15 \cdot 8$ \\
Surface area $\left(\mathrm{m}^{2} / \mathrm{g}\right)$ & BET & $7 \cdot 98$ & $9 \cdot 50$ \\
True density $\left(\mathrm{g} / \mathrm{cm}^{3}\right)$ & Picnometer & $2 \cdot 3$ & $2 \cdot 3$ \\
Bulk density $\left(\mathrm{g} / \mathrm{cm}^{3}\right)$ & IS K-5101 & 0.086 & 0.084 \\
\hline
\end{tabular}

${ }^{\star}$ Geometric SD. body fluids, this result suggests that the MOSHIGE is easily dissolved in the lung.

The measured magnesium content in the long whiskers and short whiskers was $32 \cdot 7 \%$ and $31.4 \%$, respectively. These values were close to that calculated from the structural formula (31.3\%). Many other trace elements, including $\mathrm{Ca}, \mathrm{Si}, \mathrm{Al}$, and $\mathrm{Fe}$ were detected, but total content of these components were less than $1 \%$.

Table 3 Solubility, $p H$, and zeta potential of short whiskers in various solutions

\begin{tabular}{llll}
\hline Solution & $\begin{array}{l}\text { Solubility } \\
(\mathrm{mg} / \mathrm{l})\end{array}$ & $\mathrm{pH}$ & $\begin{array}{l}\text { Zeta potential } \\
(\mathrm{mV})\end{array}$ \\
\hline Distilled water & $29 \cdot 9$ & $10 \cdot 6$ & $-0 \cdot 7$ \\
Saline & 50.5 & $10 \cdot 7$ & $-7 \cdot 8$ \\
Gamble's solution & $467 \cdot 6$ & $9 \cdot 7$ & $-9 \cdot 0$ \\
Phosphoric acid buffer & 123.5 & $9 \cdot 6$ & - \\
\hline
\end{tabular}

pancreas, and spleen were routinely sampled, and tumours of other organs, if present, were also taken, the tissues were all fixed in $10 \%$ formalin, dehydrated in an ethanol series, and embedded in paraffin for histological examination.

\section{Results}

PHYSICAL AND CHEMICAL CHARACTERISTICS OF WHISKERS

Figure 2 shows photographs of the short whiskers and long whiskers taken under the scanning electron microscope. The whiskers had large aspect ratios, and the number of non-fibrous particles were few. Most of the whiskers were cylindrical, but whiskers with branched ends were also seen.

Tables 2 and 3 summarise the physical and chemical properties of crude whiskers. As the chemical structures of the short whiskers and long whiskers are the same, the solubility, $\mathrm{pH}$ and zeta potential were measured only for the short whiskers. When the whiskers were put into each fluid, the magnesium concentration in the solutions, - that is, an index of the dissolved amount of whiskers-and $\mathrm{pH}$ increased rapidly at first, then approached to a constant value. As the concentration became almost constant when the dissolution time was 120 minutes, the solubility and $\mathrm{pH}$ given in table 3 were the values at 120 minutes. The values for the solubility, $\mathrm{pH}$ and zeta potential depended on the fluid. In particular, the solubility of the whiskers in Gamble's solution was much greater than that in distilled water and physiological saline. Because the composition of the Gamble's solution is similar to that of

\section{INTRATRACHEAL INSTILLATION}

Table 4 shows the magnesium content in hamster lungs after intratracheal instillation. Magnesium was removed rapidly from the lungs. The table also shows the residual amount of short whiskers per lung calculated from the measured amount of magnesium. Because magnesium content in the control rats was high, the deposited amounts of magnesium in the exposed rats were estimated by subtracting the amounts of magnesium in the controls from that in the exposures. The column (1) of the residual amount of the short whiskers in table 4 shows the estimated residual amounts of the short whiskers in the lungs obtained by subtracting the average amounts of magnesium per lung weight of the controls (equation 1):

Amount of fibres $=W_{I E}\left(\frac{M g_{E}}{W_{L E}}-\frac{M g_{C}}{W_{L C}}\right) \times \frac{100}{31 \cdot 3}(1)$

where, $\mathrm{Mg}_{\mathrm{E}}$ and $\mathrm{W}_{\mathrm{LE}}$ are the amounts of magnesium in the lungs and the lung weights of the exposed hamsters, and $\mathbf{M g}_{\mathrm{C}}$ and $\mathrm{W}_{\mathrm{LC}}$ are the average values of the amounts of magnesium in the lungs and the lung weights of the control hamsters. The value $100 / 31.3$ is the conversion factor from magnesium to magnesium sulphate whiskers.

As shown in table 4, however, the average lung weights of the exposed groups were significantly greater than those of the control group except for the 10 minutes clearance period. The reason for this may be that the lung weights were changed by the injected fluid because the dissection times after the instillation were so short. As the periods until the dissection of the controls were longer than the exposure groups, a part of the injected liquid in the control rats could already have been absorbed and transferred into the body fluids.

If this is the case, the correction for body weight may be more suitable because the body weights were not significantly different between the control and the exposure groups.

Table 4 Magnesium content and residual amount of short whiskers in hamster lungs: intratracheal instillation study

\begin{tabular}{|c|c|c|c|c|c|}
\hline \multirow[b]{2}{*}{$\begin{array}{l}\text { Period } \\
\text { (min) }\end{array}$} & \multirow[b]{2}{*}{$\begin{array}{l}\text { Body } \\
\text { weight } \\
\text { (g) }\end{array}$} & \multirow[b]{2}{*}{$\begin{array}{l}\text { Lung weight } \\
(g)\end{array}$} & \multirow{2}{*}{$\begin{array}{l}\text { Magnesium } \\
\text { content in } \\
\text { the lung } \\
(\mu g)\end{array}$} & \multicolumn{2}{|c|}{ Residual amount of short whiskers } \\
\hline & & & & $\begin{array}{l}\text { (1) } \\
\text { ( } \mu g / g \text { lung) }\end{array}$ & $\begin{array}{l}(2) \\
(\mu g / g \text { lung })\end{array}$ \\
\hline $\begin{array}{l}0 \text { (control) } \\
10 \\
20 \\
40 \\
60 \\
80\end{array}$ & $\begin{array}{l}121(7) \\
119(8) \\
122(12) \\
122(5) \\
119(12) \\
126(5)\end{array}$ & $\begin{array}{l}0.54(0.05) \\
0.61(0.05) \\
0.70(0.09)^{* *} \\
0.67(0.03)^{* *} \\
0.67(0.09)^{* *} \\
0.67(0.03)^{* *}\end{array}$ & $\begin{array}{c}81.4(8.6) \\
321.1(17.0) \\
277.5(19.8) \\
173.9(10.5) \\
135.3(12.6) \\
119.9(8.3)\end{array}$ & $\begin{array}{r}729.9(44 \cdot 1) \\
548.0(80.6) \\
228.9(20.0) \\
110.8(12.9) \\
61.4(13.1)\end{array}$ & $\begin{array}{r}755 \cdot 1(45 \cdot 5) \\
608 \cdot 5(37 \cdot 5) \\
275 \cdot 4(34 \cdot 2) \\
160 \cdot 1(25 \cdot 3) \\
95 \cdot 3(23 \cdot 2)\end{array}$ \\
\hline
\end{tabular}

${ }^{\star} \mathrm{p}<0.05 ;{ }^{\star \star} \mathrm{p}<0.01 v$ controls.

(1) = calculated by equation $1 ;(2)=$ calculated by equation 2 . 
Table 5 Weights of body and organs: subchronic inhalation study

\begin{tabular}{|c|c|c|c|c|c|c|}
\hline & $n$ & Body weight (g(SD)) & Lung (g(SD)) & Liver $(g(S D))$ & Kidneys (g(SD)) & Spleen $(g(S D))$ \\
\hline \multicolumn{7}{|l|}{1 week: } \\
\hline Control & 5 & $203.0(6.0)$ & $1.10(0.19)$ & $6.06(0.23)$ & $1.61(0.09)$ & $0.58(0.04)$ \\
\hline Short whisker & 5 & $204 \cdot 2(4.9)$ & $1.03(0.12)$ & $5.96(0.29)$ & $1.54(0.05)$ & $0.59(0.07)$ \\
\hline Long whisker & 5 & $197 \cdot 8(5 \cdot 7$ & $1.00(0.06)$ & $5.76(0.44)$ & $1.50(0.12)$ & $0.53(0.05)$ \\
\hline \multicolumn{7}{|l|}{2 weeks: } \\
\hline $\begin{array}{l}\text { Control } \\
\text { Short whisker }\end{array}$ & 5 & $255 \cdot 8(12.4)$ & $1.15(0.07)^{*}$ & $7.31(0.53)$ & $\begin{array}{l}1.65(0.11) \\
1.70(0.12)\end{array}$ & $\begin{array}{l}0.71(0.07) \\
0.78(0.24)\end{array}$ \\
\hline $\begin{array}{l}\text { Short whisker } \\
\text { Long whisker }\end{array}$ & 5 & $248 \cdot 2(9 \cdot 0)$ & $1.10(0.06)^{*}$. & $6.89(0.29)$ & $1.70(0.12)$ & $0.78(0.24)$ \\
\hline \multicolumn{7}{|l|}{3 weeks: } \\
\hline Control & 5 & $286.0(14.9)$ & $1.17(0.08)^{*}$ & $7.81(0.55)$ & $1.95(0.12)$ & $0.70(0.07)$ \\
\hline Short whisker & 5 & $288.6(16 \cdot 1)$ & $1.20(0.06)^{*}$ & $8.48(0.66)$ & $1.95(0.14)$ & $0.74(0.08)$ \\
\hline Long whisker & 5 & $281.4(19.0)$ & $1.17(0.06)^{*}$ & $7.60(0.69)$ & $1.83(0.08)$ & $0.69(0.05)$ \\
\hline \multicolumn{7}{|l|}{4 weeks: } \\
\hline Control & 5 & $323.4(21 \cdot 1)$ & $1.22(0.07)^{*}$ & $8.19(0.63)$ & $2.01(0.23)$ & $0.74(0 \cdot 10)$ \\
\hline Short whisker & 5 & $317 \cdot 6(14 \cdot 3)$ & $1.24(0.04)^{*}$ & $8.36(0.51)$ & $1.98(0.08)$ & $0.79(0.10)$ \\
\hline Long whisker & 5 & $309 \cdot 6(32 \cdot 2)$ & $1.19(0.09)^{*}$ & $7 \cdot 85(0.85)$ & $1.94(0.28)$ & $0.68(0 \cdot 16)$ \\
\hline \multicolumn{6}{|l|}{4 weeks -2 months: } & \\
\hline Short whisker & $\begin{array}{l}3 \\
5\end{array}$ & $373.2(26.8)$ & $1.27(0.08)^{*}$ & $9.09(0.70)$ & $2.26(0.26)$ & $\begin{array}{l}0.17(0.13) \\
0.81(0.15)\end{array}$ \\
\hline Long whisker & 5 & $382 \cdot 2(28 \cdot 8)$ & $1.34(0.13)^{*}$ & $9.91(1.06)$ & $2.29(0.21)$ & $0.90(0.10)$ \\
\hline \multicolumn{7}{|l|}{4 weeks -4 months: } \\
\hline Control & 5 & $414 \cdot 2(38 \cdot 1)$ & $1.49(0.07)^{*}$ & $10.57(0.89)$ & $2.33(0.21)$ & $0.78(0.09)$ \\
\hline Short whisker & 5 & $405 \cdot 8(37 \cdot 8)$ & $1.33(0.11)^{*}$ & $9.73(1.63)$ & $2.29(0.32)$ & $0.82(0.04)$ \\
\hline Long whisker & 5 & $398 \cdot 2(29 \cdot 1)$ & $1.37(0.07)^{*}$ & $9.76(0.74)$ & $2 \cdot 28(0.18)$ & $0.82(0.07)$ \\
\hline \multicolumn{7}{|l|}{4 weeks -6 months: } \\
\hline $\begin{array}{l}\text { Control } \\
\text { Short whisker }\end{array}$ & $\overline{6}$ & $\overline{599} \cdot 8(38.3)$ & $\overline{1.64}(0.07)$ & $\overline{13} .42(0.99)$ & $\overline{2.63}(0.22)$ & $\overline{0.94}(0.07)$ \\
\hline Long whisker & 6 & $567 \cdot 2(62 \cdot 2)$ & $1.57(0.30)$ & $12.37(2.08)$ & $2.52(0.40)$ & $0.94(0.13)$ \\
\hline \multirow{4}{*}{$\begin{array}{l}4 \text { weeks-12 months: } \\
\text { Control } \\
\text { Short whisker } \\
\text { Long whisker }\end{array}$} & & & & & & \\
\hline & 6 & $626 \cdot 0(65 \cdot 0)$ & $1.73(0.15)$ & $12.43(1.68)$ & $2.92(0.29)$ & $0.86(0 \cdot 14)$ \\
\hline & 6 & $665.0(101.5)$ & $1.95(0.52)$ & $14 \cdot 13(2 \cdot 80)$ & $3.39(0.71)$ & $1.00(0 \cdot 12)$ \\
\hline & 6 & $678 \cdot 8(154 \cdot 6)$ & $1.96(0.49)$ & $13.89(3.45)$ & $3.23(0.55)$ & $0.89(0.17)$ \\
\hline
\end{tabular}

$\star_{n}=4$.

The column (2) in the table shows the calculated amount of the short whiskers estimated by the amount of magnesium in the lungs with correction for average body weight of the control hamsters (equation 2):

Amount of fibres $=W_{E}\left(\frac{M g_{E}}{W_{E}}-\frac{M g_{C}}{W_{C}}\right) \times \frac{100}{31 \cdot 3}(2)$

where, $W_{E}$ is the body weight of the exposed rats and $W_{C}$ is the average body weight of the control rats.

The injected amount of short whiskers was $1100 \mu \mathrm{g}(1 \cdot 1 \mathrm{mg})$. Therefore, the results in table 4 indicate that the residual amounts of short whiskers decreased to less than one tenth at 80 minutes after the instillation.

\section{INHALATION STUDY}

Growth curves and survival rate of rats

The growth curves of the groups were almost identical during all observed periods including the exposure and clearance periods for both the subchronic and chronic studies.

Figure 3 shows the survival rate during the clearance period in the chronic study. Forty eight per cent $(10 / 21), 41 \%(9 / 22)$, and $30 \%$ $(6 / 20)$ of rats died during the one year clear-

Figure 3 Survival rate during clearance time. $\diamond$ control; $\Delta$ short whiskers exposure; long whiskers exposure.

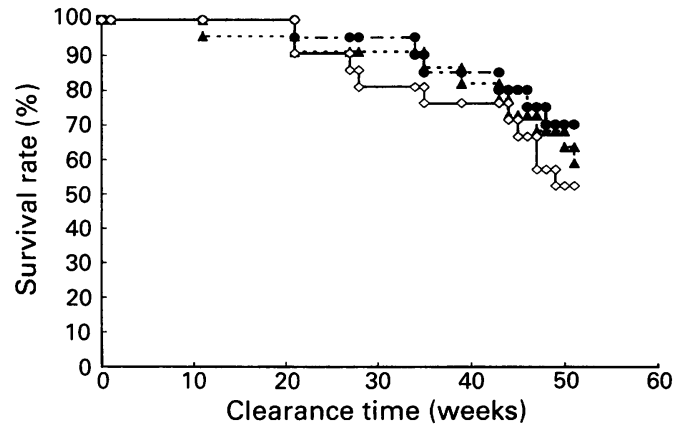

ance time in the controls, the short whisker, and long whisker exposure groups, respectively. This indicates that exposure to MOSHIGE did not reduce the survival rate.

Weights of body and organs

Tables 5 and 6 show the average weights of body, lung, liver, kidneys, and spleen of the three groups at each dissection time in the

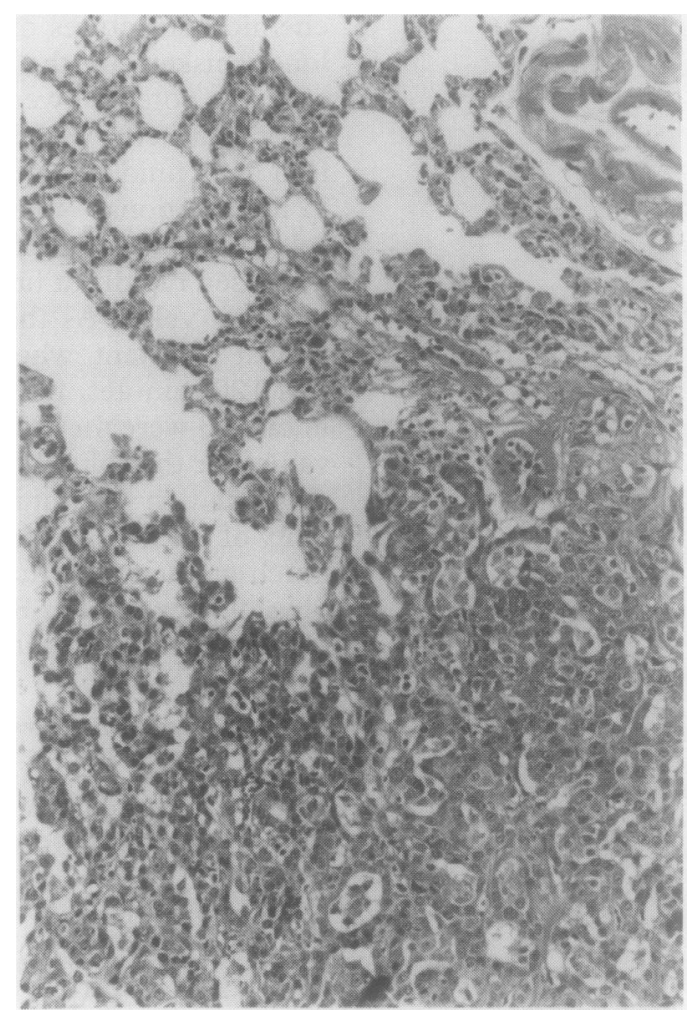

Figure 4 Pulmonary adenoma (lower) composed of irregular small glands with enlarged nuclei; haematoxylin and eosin. 
Table 6 Weights of body and organs: chronic inhalation study

\begin{tabular}{|c|c|c|c|c|c|c|}
\hline $\begin{array}{l}\text { Time after end of } \\
\text { exposure }\end{array}$ & $n$ & Body weight $(g(S D))$ & Lung (g(SD)) & Liver $(g(S D))$ & Kidneys (g(SD)) & Spleen $(g(S D))$ \\
\hline \multicolumn{7}{|l|}{1 day: } \\
\hline $\begin{array}{l}\text { Control } \\
\text { Short whisker } \\
\text { Long whisker }\end{array}$ & $\begin{array}{l}5 \\
5 \\
5\end{array}$ & $\begin{array}{l}663 \cdot 4(66 \cdot 3) \\
642 \cdot 8(49 \cdot 2) \\
691 \cdot 6(77 \cdot 1)\end{array}$ & $\begin{array}{l}1.77(0.19) \\
1.57(0.16) \\
1.92(0.15)\end{array}$ & $\begin{array}{l}13.22(1.24) \\
12.60(1.02) \\
14.12(1.43)\end{array}$ & $\begin{array}{l}2.71(0.28) \\
2.60(0.17) \\
3.19(0.40)\end{array}$ & $\begin{array}{l}0.98(0.14) \\
0.97(0.09) \\
1.00(0.09)\end{array}$ \\
\hline $\begin{array}{l}1 \text { year: } \\
\text { Control }\end{array}$ & & & & & & \\
\hline $\begin{array}{l}\text { Control } \\
\text { Lhort whisker } \\
\text { Long whisker }\end{array}$ & $\begin{array}{l}11 \\
13 \\
14\end{array}$ & $\begin{array}{l}759 \cdot 3(115 \cdot 1) \\
739 \cdot 0(167 \cdot 7) \\
715 \cdot 2(107 \cdot 1)\end{array}$ & $\begin{array}{l}1.94(0.22) \\
1.85(0.17) \\
1.85(0.14)\end{array}$ & $\begin{array}{l}16.20(2.06) \\
15.66(3.14) \\
15.66(2.88)\end{array}$ & $\begin{array}{l}3.65(0.35) \\
3.51(0.44) \\
3.70(0.57)\end{array}$ & $\begin{array}{l}1.32(0.26) \\
1.51(0.64) \\
1.19(0.24)\end{array}$ \\
\hline
\end{tabular}

subchronic and chronic studies. No significant differences were found among the groups.

\section{Magnesium content of the lungs}

Table 7 shows the amounts of magnesium in the lungs during the exposure periods in the subchronic study. The magnesium content did not increase even when the exposure periods lengthened from one to four weeks. The amount of magnesium in the rats after exposure to the long whiskers for two and three weeks was significantly greater than that after one week $(p<0.05)$. It should not be considered that the average magnesium content increased but rather magnesium content in the one week exposure group was smaller than the others, because the values were not greater than those in the control group for all exposure periods. The magnesium concentrations in the short whisker group were almost identical with those in the long whisker and control groups.

\section{Histopathological findings}

Table 8 summarises the overall histological data for all rats. Just after exposure there were no significant lesions, including tumours, in any organs, irrespective of group.

In the rats with four week exposure and a one year clearance period, one pulmonary adenoma was found, in the short whisker exposure group. Segmental calcifications of the pulmonary artery were found more often in the short whisker and long whisker expo-

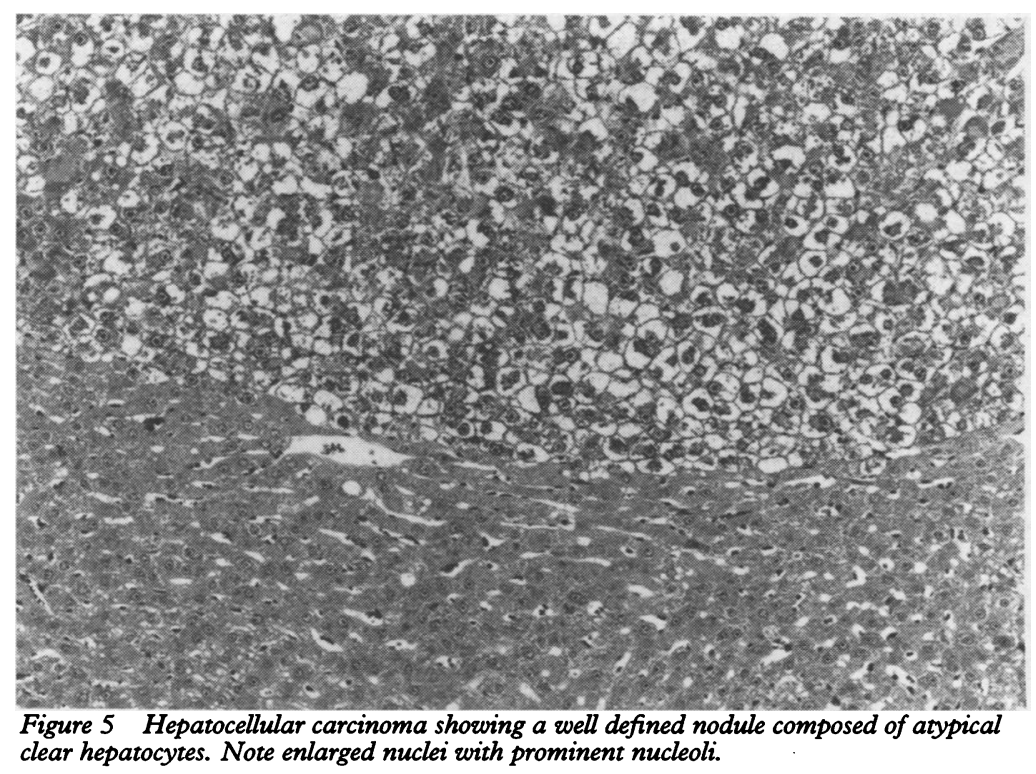

Table 7 Magnesium content in the rat lung: subchronic inhalation study

\begin{tabular}{|c|c|c|c|}
\hline \multirow[b]{2}{*}{$\begin{array}{l}\text { Period } \\
\text { (weeks) }\end{array}$} & \multirow[b]{2}{*}{$\begin{array}{l}\text { Control } \\
\text { ( } \mu \text { g/g lung) }\end{array}$} & \multicolumn{2}{|l|}{ Exposed } \\
\hline & & $\begin{array}{l}\text { Long whisker } \\
\text { ( } \mu \text { glg lung) }\end{array}$ & $\begin{array}{l}\text { Short whisker } \\
\text { ( } \mu \text { g/g lung) }\end{array}$ \\
\hline $\begin{array}{l}1 \\
2 \\
3 \\
4\end{array}$ & $\begin{array}{l}132 \cdot 0(15 \cdot 6) \\
134 \cdot 2(2 \cdot 3) \\
134 \cdot 2(2 \cdot 3) \\
132 \cdot 5(3 \cdot 2)\end{array}$ & $\begin{array}{l}122 \cdot 2(8 \cdot 1) \\
131.3(1 \cdot 2) \dagger \\
131.5(1 \cdot 4) \dagger \\
130.0(6.9)\end{array}$ & $\begin{array}{l}124.7(11.8) \\
129.9(2.5)^{\star} \\
133.3(3.4) \\
134.8(1.7)\end{array}$ \\
\hline
\end{tabular}

tp $<0.05$ compared with one week exposure to long whiskers.

sure groups than in the control group, although the difference was not significant $(\mathrm{p}<0 \cdot 2)$.

In the rats with one year clearance after the one year exposure, several neoplastic lesions were found in both experimental and control groups. Two, two, and one pulmonary adenoma occurred in the short whisker, long whisker, and the control groups, respectively. One of them showed a pronounced epithelial atypia, but this was not conclusive of carcinoma (fig 4). The number of adenomas in the exposure groups was not significantly greater than that of the control group. Hepatocellular adenoma and carcinoma (fig 5) occurred somewhat more often in the long whisker group than in the control groups.

\section{Discussion}

MOS-HIGE consists of crystals of magnesium sulphate and magnesium hydroxide. Therefore, the amount of inhaled whiskers can be determined by measuring the amount of magnesium in the lungs. There were no significant differences, however, in the magnesium content in the lungs between exposed

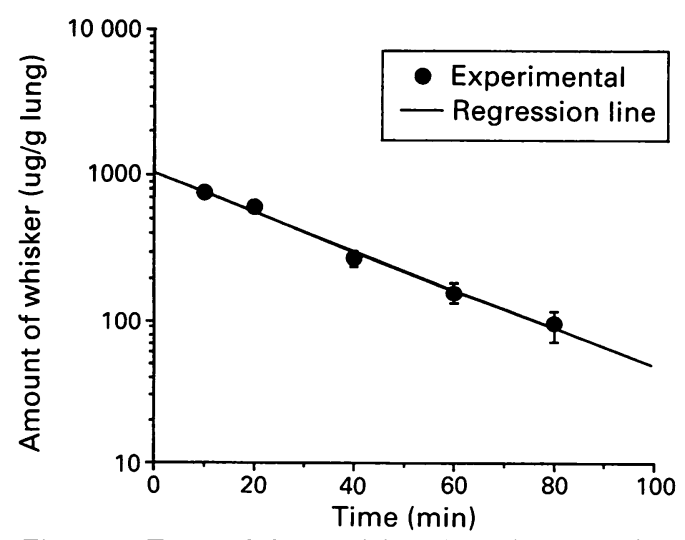

Figure 6 Temporal change of the estimated amount of short whiskers in the hamster lung. The values were corrected by body weight (equation 2). 
Table 8 Summary of histopathological features

\begin{tabular}{|c|c|c|c|c|c|c|c|c|c|}
\hline & \multicolumn{3}{|c|}{ One day after one year exposure } & \multicolumn{3}{|c|}{ One year after four weeks exposure } & \multicolumn{3}{|c|}{ One year after one year exposure } \\
\hline & Short whisker & Long whisker & Control & Short whisker & Long whisker & Control & Short whisker & Long whisker & Control \\
\hline No of rats & 5 & 5 & 5 & 6 & 6 & 6 & 13 & 14 & 11 \\
\hline \multicolumn{10}{|l|}{ Pulmonary lesions: } \\
\hline Thickening of the pleura & 0 & 1 & 0 & 3 & 1 & 2 & 4 & 6 & 3 \\
\hline Calcification of pulmonary artery & 0 & 3 & 1 & 4 & 3 & $\overline{1}$ & 6 & 5 & 2 \\
\hline Squamous metaplasia & 0 & 0 & 0 & 0 & 1 & 0 & 0 & 0 & 0 \\
\hline Aggregate of form cells & 0 & 0 & 0 & 2 & 2 & 1 & 0 & 2 & 0 \\
\hline \multicolumn{10}{|l|}{ Pulmonary tumour: } \\
\hline Adenoma & 0 & 0 & 0 & 0 & 1 & 0 & 2 & 2 & 1 \\
\hline Squamous cell carcinoma & 0 & 0 & 0 & 0 & 0 & 0 & 0 & 0 & 0 \\
\hline \multicolumn{10}{|l|}{ Extrapulmonary lesions: } \\
\hline \multicolumn{10}{|l|}{ Pancreas } \\
\hline Acinic cell adenoma & 0 & 0 & 0 & 0 & 0 & 1 & 2 & 1 & 0 \\
\hline Islet cell adenoma & 0 & 0 & 0 & 0 & 0 & 0 & 2 & $i$ & 1 \\
\hline \multicolumn{10}{|l|}{ Kidney: } \\
\hline Pyelonephritis & 3 & 1 & 0 & 2 & 0 & 0 & 0 & 6 & 0 \\
\hline Infarct & 0 & 0 & 0 & 0 & 0 & 0 & 0 & 1 & 1 \\
\hline \multicolumn{10}{|l|}{ Liver: } \\
\hline Hepatocellular adenoma & 0 & 0 & 0 & 0 & 0 & 0 & 0 & 1 & 0 \\
\hline Hepatocellular carcinoma & 0 & 0 & 0 & 0 & 0 & 0 & 1 & 0 & 0 \\
\hline \multicolumn{10}{|l|}{ Soft tissue tumour: } \\
\hline Fibroma & 0 & 0 & 0 & 0 & 0 & 0 & 0 & 1 & 1 \\
\hline Sarcoma (fibrosarcoma) & 0 & 0 & 0 & 0 & 0 & 0 & 1 & 0 & 0 \\
\hline Salivary gland adenoma & 0 & 0 & 0 & 0 & 0 & 0 & 0 & 0 & 0 \\
\hline Pituitary adenoma & 0 & 0 & 0 & 0 & 0 & 2 & 2 & 1 & 0 \\
\hline
\end{tabular}

and control rats (table 7). One possible reason is that magnesium content in the control rat lungs is so high that the deposited amount of magnesium is within the errors of experiments and analysis. To examine whether this was true or not, we estimated the deposited amount of magnesium by inhalation in rat lungs.

The deposited amount of the whiskers can be estimated by:

$$
\begin{aligned}
& \text { Deposited amount }(\mu \mathrm{g})=\text { concentration }(\mu \mathrm{g} / m l) \\
& \times \text { total exposure time }(\mathrm{min}) \\
& \quad \times \text { respiration rate }(\mathrm{ml} / \mathrm{min}) \\
& \times \text { deposition fraction }(-)
\end{aligned}
$$

For equation 3 , the whisker concentration and total exposure time are as shown in table 1 , and the respiration rate can be estimated from the Guyton formula:

$$
\begin{array}{r}
\text { Respiration rate }(\mathrm{ml} / \mathrm{min})= \\
2 \cdot 1 \times(\text { body weight })^{3 / 4}
\end{array}
$$

The deposition fraction of the whiskers in the lungs could not be determined. In the case of non-fibrous particles, however, Raabe et al ${ }^{18}$ showed that the deposition fraction in the rat pulmonary region was $11 \cdot 0(0 \cdot 2) \%$ and $6 \cdot 6(0.5) \%$ for particles with $1.03 \mu \mathrm{m}$ and $3 \cdot 11$ $\mu \mathrm{m}$ aerodynamic diameter respectively. As the median aerodynamic diameters of short whiskers and long whiskers are 1.5 and 1.8 $\mu \mathrm{m}$, the corresponding deposition fractions were estimated to be $10 \%$ and $9.4 \%$ respectively. By substituting these values in equation 3 , the deposited amount of the whiskers was estimated as $219-1050 \mu \mathrm{g} / \mathrm{g}$ lung. Because the magnesium content in the whiskers is about $32 \%$, the amount of magnesium deposited was $70-336 \mu \mathrm{g} / \mathrm{g}$ lung. These values are much greater than the SD of magnesium content in the control rats, so magnesium should be detected if the deposited whiskers are not eliminated. Only limited numbers of whiskers were found in the lungs (with an optical microscope) even just one day after the inhalation exposure. These results suggested that the MOS-HIGE was so soluble in the body fluid that the inhaled whiskers were dissolved almost completely within a day. This was qualitatively supported by the experimental results on the solubility of the short whiskers (table 3 ).

To confirm this experimentally we tried to expose rats to a high concentration of whiskers by inhalation. The dissolution rate was so great, however, that it was impossible to determine the initial amounts of the whiskers even just after the end of the exposure. Therefore, an intratracheal instillation was conducted to find the exact amount of whiskers in the lung at initial time. Hamsters were used for the instillation study instead of rats because we could easily find the trachea. The results show that the amount of magnesium was reduced rapidly (table 4 ).

Figure 6 shows a semi-log plot of the estimated amount of residual whiskers in the lungs as estimated by equation 2 . The amounts of whiskers decreased almost exponentially, suggesting that the clearance of MOS-HIGE from the lungs could be explained by a single compartment model. From the slope of the regression line (solid line), the half life of clearance of the whiskers in the lungs was determined to be $17.6 \mathrm{~min}-$ utes. This result indicates that the amounts of magnesium in the lungs reduced to a control level within a few hours. This finding coincides with the result that the whiskers could not be detected from the rat lungs even at one day after exposure to MOS-HIGE in the inhalation studies.

Optical microscopy found no whiskers in any organ, including liver, kidney, and spleen. Fibrosis and pneumoconiosis, commonly observed in lungs exposed to other fibrous particles for a long period, were not recognised. These results can also be explained that the whiskers are so soluble that they cannot exist in the organs.

In the histopathological examination, several neoplastic lesions and pulmonary adenomas were found in both the one year short whisker and long whisker exposure groups. 
The incidence of hepatocellular adenoma and carcinoma in the long whisker group tended to be higher than in the control group. But the differences were not significant. The major cause may be age because these rats were more than two years old at the end of the experiments.

The main reason why the histopathological findings were not significantly different between the control and exposure groups may be because the MOS-HIGE is so soluble, as confirmed by the intratracheal study. If no whiskers exist in the body, there should be no effects. When large amounts of the whiskers are present at one time, however, some biological effects may be possible.

Adachi et al ${ }^{10}$ studied the oxidative damage to DNA, which is an index of carcinogenicity, of asbestos and several MMMFs including magnesium sulphate whiskers in vitro. They measured the yield of 8-hydroxy-2'deoxyguanosine (8-OH-dGuo) from calf thymus DNA incubated with fibres and $\mathrm{H}_{2} \mathrm{O}_{2}$, $\mathrm{FeSO}_{4}$, EDTA, or mannitol. The formation of 8-OH-dGuo by magnesium sulphate whiskers was the same as or less than the control level except for one case (DNA with $10 \mathrm{mM}$ mannitol). This indicates that the carcinogenicity of magnesium sulphate whisker is low, consistent with our results. Adachi et al ${ }^{11}$ also showed, however, that nine of 20 female Syrian hamsters that were intratracheally injected with $10 \mathrm{mg}$ of basic magnesium sulphate whiskers had tumours within two years of the exposure.

In our inhalation study, the incidence of tumours in the exposure group was larger but not significantly so than that in the controls. Our experimental data could not be compared directly with theirs because the experimental conditions-namely, exposure methods, dose, and animals - were different. In work environments, however, inhalation is the major route of exposure, so our results are relevant to the understanding of the health effects of magnesium sulphate whiskers.

The effects of airborne fibrous particles may depend not only on their geometric characteristics but also on other physical and chemical properties. In particular, the solubility gives an estimate of the durability of fibres that is an important factor in biological effects. This means that it is necessary to know the physical and chemical characteris- tics of fibres to fully understand the biological effects of the fibres. Therefore, when the biological effects of new fibrous materials are examined, the physical and chemical characteristics of the fibres including geometric sizes and solubility should be determined in advance of both in vivo and in vitro studies.

1 Stanton MF, Layard M, Tegeris A, et al. Relation of particle dimension to carcinogenicity in amphibole asbestoses and other fibrous minerals. $\mathcal{f}$ Natl Cancer Inst 1981; 67:965-75.

2 Pott F. Some aspects of the dosimetry of the carcinogenic potency of asbestos and other fibrous dusts. Staub Reinhault Luft 1978;38:484-490.

3 Pott F, Ziem U, Reiffer FJ, Huth F, Ernst H, Mohr U. Carcinogenicity studies on fibres, metal compounds,
and some other dusts in rats. Experimental Pathology and some other

4 Bellmann $B$, Muhle $H$, Pott $F$, König $H$, Klöppel $H$, Spurny K. Persistence of man-made mineral fibres(MMMF) and asbestos in rat lungs. Ann Occup Hyg 1987;31:693-709.

5 Pigott GH, Ishmael $\mathrm{J}$. The effects of intrapleural injections of alumina and aluminosilicate (ceramic) fibres. Int $\mathcal{f}$ Exp Pathol 1992;73:137-46.

6 Koshi K, Kohyama N, Myojo T, Fukuda K. Cell toxicity, hemolytic action and clastogenic activity of asbestos and its substitutes. Ind Health 1991;29:37-56.

7 Leanderson $P$, Soderkvist P, Tagesson C. Hydroxyl radical mediated DNA base modification by manmade mineral mediated DNA base modification by

8 Brown RC, Sara EA, Hoskins JA, et al. The effects of heating and devitrification on the structure and biological ing and devitrification on the structure and biological activity of aluminosilicate refrac
Occup Hyg 1992;36:115-29.

9 Adachi S, Takemoto K, Kimura K. Tumorigenicity of fine man-made fibers after intratracheal administration to hamsters. Environ Res 1991;54:52-73.

10 Adachi S, Kawamura K, Yoshida S, Takemoto K Oxidative damage on DNA induced by asbestos and man-made fibers in vitro. Int Arch Occup Environ Health 1992;63:553-7.

11 Adachi S, Kawamura K, Kimura K, Takemoto K. Tumor incidence was not related to the thickness of visceral pleural in female Syrian hamsters intratracheally administered amphibole asbestos or manmade fibers. Environ Res 1992;58:55-65.

12 Light WG, Wei ET. Surface charge and a molecular basis for asbestos toxicity. In: Brown RC, Chamberlain M, for asbestos toxicity. In: Brown RC, Chamberiain M, London, Academic Press, 1980:139.

13 Moncheaux G, Bignon J, Jaurand MC, et al. Mesothelioma in rats following inoculation with acid leached chrysotile asbestos and other mineral fibres, Carcinogenesis 1981;2:229.

14 World Health Organisation. Reference method using a scanning electron microscope to determine size of airborne MMMF in the workplace. In Dodgson J, ed. Reference methods for measuring airborne man-made mineral Reference methods for measuning airbort man-made mineral WHO, 1985:36-54.

15 Japanese Industrial Standards Committee. fIS $R$ 5101-1978. Tokyo: Japanese Standards Association, $5101-197$.
1978.

16 Japanese Industrial Standards Committee. Method for chemical analysis of Portland cement, FIS $R$ 5202-1989. Tokyo: Japanese Standards Association, 1989.

17 Tanaka I, Akiyama T. Fibrous particles generator for inhalation toxicity studies. Ann Occup Hyg 1987;31: 401-3.

18 Raabe OG, Al-Bayati MA, Teague SV, Rasolt A. Regional deposition of inhaled monodisperse coarse and fine aerosol particles in small laboratory animals, In Dodgson J, McCallum RI, Bailey MR, Fisher DR, eds. Inhalation particles VI. Oxford: Pergamon Press, 1988:53-63. 